\title{
Editorial introduction: Philipp Frank, a physicist-turned-philosopher
}

\author{
Adam Tamas Tuboly ${ }^{1,2}$
}

Published online: 4 September 2017

(C) Springer Science+Business Media B.V. 2017

Philipp Frank [...] undermined common ideas of rationality in a different way by showing that the arguments against Copernicus had been perfectly sound and in agreement with experience while Galileo's procedures were 'unscientific' when viewed from a modern standpoint. [...] Frank's work has been treated quite unfairly [...]. Also his ideas are now commonplace. But it was he who announced them when almost everyone thought differently. (Feyerabend 1988: 277.)

2016 marked the 50th anniversary of Philipp Frank's (1884-1966) death. As a physicist-turned-philosopher, Frank played an important role in developing the Vienna Circle's scientific world-conception [wissenschaftliche Weltauffassung] in Vienna and later in Prague with Rudolf Carnap. He was also responsible for the dissemination of the ideas of logical empiricism and modern scientific thought for the layman, which task he continued in the United States through the institutionalization of the unified science movement. This special issue aims to bring new perspectives to the texts and contexts of Frank, originating in a special EasternEuropean context, to understand the rise and decline of his thinking, (meta-) philosophical commitments, and projects.

Frank's career might be divided into three phases, characterized by different persons and places, but by (fundamentally) overlapping ideas and commitments: (1) The early 1900s, until 1912, Vienna; (2) 1912-1938, Prague; (3) 1938-1966, United States, Boston (Harvard).

Adam Tamas Tuboly

tuboly.adam@btk.mta.hu

1 Institute of Philosophy, Hungarian Academy of Sciences, Budapest, Hungary

2 University of Pécs, Baranya, Hungary 
(1) Frank studied mathematics and physics at the Universities of Vienna and Göttingen under, for example, Ludwig Boltzmann, Felix Klein, and David Hilbert. He obtained his doctorate in physics in 1906 at the University of Vienna and habilitated there just 2 years later (allowing him to teach officially at the university as a so-called Privatdozent until 1912). In his Habilitationsschrift, he discussed the principle of relativity which became a life-long issue for him.

During his formative years, Frank's most determining experience was the socalled the First Vienna Circle. He (1949: 1) used to discuss the new achievements of (natural and human) sciences, philosophy, as well as "a great variety of political, historical, and religious problems [...] as scientifically as possible" with Hans Hahn, Otto Neurath, and Richard von Mises. Though, as Friedrich Stadler (2001/2015: 13-14) pointed out, during these discussions most of the later commitments of the Vienna Circle already surfaced, one of the most important events, at least for Frank (1949: 2-4), was the reading of Abel Rey's Physical Theory according to Contemporary Physicists. That book prompted Frank to study the relation between science, philosophy and worldviews [Weltanschauungen]; his interest in these questions evolved later into his mature philosophy of science.

(2) Though after 1912 Frank often visited his hometown to participate in the meetings of the Vienna Circle, he moved to Prague when he was promoted to "Ordinary Professor of Theoretical Physics" at the German University of Prague as a successor of Albert Einstein; later he became the director of the Institute of Theoretical Physics until his emigration to the United States in 1938.

Two important points shall be mentioned here. The first is obviously Einstein himself, who played, from that time on, an important and effective role in Frank's philosophical and scientific career and thinking. First of all, already when Frank published one of his first articles entitled "Experience and the law of causality" ("Kausalgesetz und Erfahrung") — in which he claimed that the law of causality is a 'purely conventional definition'-the paper attracted Einstein's attention and their lasting friendship began. In his recommendation and evaluation of Frank for the Prague position, Einstein (1912/1993) mentioned both the "Kausalgesetz" and another important article of Frank written jointly with Hermann Rothe (1911) about the simplification of the theory of relativity. (A later significant contribution of Frank to the natural sciences was an important two-volume handbook, Differential and Integral Equivalence in Mechanics and Physics (1927) co-edited with his old Viennese friend, Richard von Mises, and usually referred to as "The Frank-Mises"; see Siegmund-Schultze 2007.)

Einstein always esteemed Frank's publications and recommended it to others; ${ }^{1}$ actually their help and guidance functioned both ways: Frank regularly wrote on different forums positively about Einstein and his Einstein: His Life and Times (Frank 1947) became a very popular reference-point in the field. Frank wrote the book over the course of many years and he considered not just Einstein's scientific works and achievements, but also his cultural and political context, thus bringing Einstein close to educated laymen with different backgrounds.

\footnotetext{
${ }^{1}$ See Einstein's letter to Kathia Adler (February 20, 1917), Schulmann et al. (1998: 288).
} 
On the other hand, Prague was important for Frank because he started there his long educational and organizational work as an associate and advocate of the Unity of Science movement. ${ }^{2}$ This was shown, for example, by the fact that, after some opposition and repudiation, 'The First Meeting on the Epistemology of the Exact Sciences' was held in Prague (September 15-17, 1929), mainly due to the efforts of Frank (1949: 39-40). The conference was very important since it could "be viewed as marking the international establishment of the Vienna Circle" (Stadler 2001/ 2015: 153). Talks were delivered, among others, by Frank, Hahn, Neurath, von Mises, Hans Reichenbach, Friedrich Waismann, Herbert Feigl, Rudolf Carnap, and Adolf Fraenkel; they covered such themes as the Circle's general scientific worldconception (and its relation to philosophy and science), and some special questions of logic, mathematics, and probability.

The conference was not an unqualified success since it was viewed with opposition and bewilderment. Organized as part of the 'Fifth Meeting of German Physicists and Mathematicians', logical empiricists were facing German scientists' (as well as philosophers') insistence on traditional "school philosophy" (as Frank called it) and opposition to their Viennese scientific world-conception. This could also explain that Frank was able to bring about the appointment of Carnap to the Faculty of Science at the German University of Prague in 1931 only after some initial "strong opposition of the adherents of traditional philosophy" (Frank 1949: $45)^{3}$

During the following years, however, Frank and Carnap developed a "new center of 'scientific world conception' at the University of Prague" (ibid). They were quite active-in 1935 they led jointly a colloquium about the "philosophical foundations of the natural sciences" [Colloquiums für philosophische Grundlagen der Naturwissenschaft] the issue of which for the spring semester was "Physics and Biology" with Frank's opening lecture, 'What do the new theories of physics mean for the boundary issues of physics and biology?' ${ }^{4}$ Later that year, at 'The First Congress for the Unity of Science' Frank (1936) delivered a talk about the same issues. More importantly, the topic of the Copenhagen Congress (June 21-26, 1936) was based on 'The Problem of Causality - With Special Consideration of Physics and Biology' (Stadler 2001/2015: 178-182).

(3) Though Otto Neurath announced his conception of the unity of science already in Prague in 1929, the movement gained its power only after the mid-1930s. The first introductory volume of the International Encyclopedia of Unified Science (to which Frank contributed a monograph in 1946 about the Foundations of Physics) was published in 1938 by the University of Chicago Press thus gaining some international reputation for the movement. One year later, with the help of Frank

\footnotetext{
${ }^{2}$ It should be noted also that, during his Prague-phase, Frank co-edited with Moritz Schick the Schriften zur Wissenschaftiche Weltauffassung series, published between 1927 and 1939, including such influential works as Carnap's Logische Syntax der Sprache and Karl Popper's Logik der Forschung.

3 On Frank's relation to the German Physical Society see (Stöltzner 1995).

4 See Carnap's diary, March 18, 1935, ASP RC 025-75-13. Frank's philosophy of biology is treated in (Hofer 2002). Actually Carnap and Frank started their "Thursday Night Circle" [Donnerstagabendzirkel] in 1932, when they discussed Carnap's famous "The Elimination of Metaphysics Through Logical Analysis of Language” paper. See Carnap's general circular letter, March 2, 1932. ASP RC 102-67-01.
} 
(and with the support of various American scientific associations) they could spread their words personally in the United States since the 'Fifth International Congress for the Unity of Science' was held at Harvard, September 3-9, 1939. Contrary to the earlier Prague meeting, this conference was a real success with about two hundred participants from philosophy and the sciences. Though Frank earned some reputation after the Congress, he never obtained a secured and well-paid job in the United States.

Frank arrived in America in late 1938 to hold several lectures at twenty different universities. Since Czechoslovakia was invaded by the Nazis at the end of the year, he and his wife, Hania, were not able to get back to their home. Things, after all, did not work out quite well. Harvard, already having many refugees from Eastern Europe, could not offer a full-time job to Frank, but thanks to Harlow Shapley and others, he was offered a half-time, poorly paid status which had to be renewed yearby-year for a while and needed to be supplemented by further lecturing at various universities. $^{5}$

A certain continuity and temporary existential security came into Frank's life in the early 1950s when he founded and assumed the presidency of the newly established 'Institute for the Unity of Science' in Boston (1947-1958). The Institute was meant to be the official successor of Neurath's earlier European institute for the Unity of Science movement in the United States until it was closed for various, as Frank would have called them, 'extra-scientific reasons' (Reisch 2005: chapter 15). He also organized the Inter-scientific Discussion Group at Harvard, gathering most of the prominent and renowned philosophers of science at that time. ${ }^{6}$

One of the most important personalities and supporters of Frank, besides the Nobel Prize winner Percy W. Bridgman, was the famous Harvard president James B. Conant. Their friendship began at the end of 1938 when Frank held his supposedly closing lecture during his conference tour and continued when Conant gave the inaugural lecture at the Fifth Unity of Science Congress. Their joint intellectual relation was upheld during the years and "Conant [...] listened carefully to Philipp's arguments in favor of what eventually became part of Conant's chief legacy, the General Education program at Harvard College" (Holton 2006: 304). When the program started, one of the lecturers was Thomas Kuhn whose "Aristotle experience" occurred when he was preparing his presentation of the history of science (one of the fundamental issues at the program). That experience set Kuhn on the path to what later became The Structure of Scientific Revolutions (published originally in the International Encyclopedia of Unified Science).

During his whole career, three themes dominated Frank's activities (seemingly his theoretical physical research was pursued only in Vienna and in Prague, though he delivered seminars about physics in the United States too). One of them was the

\footnotetext{
5 Frank become a 'Lecturer in Physics and Mathematics' in May, 1939; 2 years later, in the fall of 1941, he acquired the status of lecturer at Harvard. He became a member of the American Academy of Arts and Sciences in 1943 as the very first among the logical empiricist refugees.

6 Frank's Inter-scientific Discussion Group was a continuation of Stanley Steven's earlier 'Science of Science Discussion Group'. The 'Inter-scientific' group became institutionalized later with the support of the Rockefeller Foundation. See (Hardcastle 2003; Reisch 2005: 294-306), and (Holton: this issue). About Frank's American period see further (Isaac 2012: chapters 4 and 6).
} 
aforementioned ideal of unified science related to the philosophy of science. In his "Ernst Mach and the unity of science" Frank provided a detailed historical and philosophical reconstruction of Mach's importance for the Unity of Science movement through economic considerations and anti-metaphysical tendencies: for Frank (1938/1949: 79), Mach was 'the spiritual ancestor' of the unity of science. ${ }^{7}$ Later, after he organized the Institute for the Unity of Science, Frank (1956/1958: 18) stated that its aim was to "attempt to encourage the investigation of the interrelation of the natural with the social sciences." He was always eager to understand and provide the link for philosophy, science, and the extra-academic context-this link was supposed to be philosophy of science:

In order to understand not only science itself but also the place of science in our civilization, its relation to ethics, politics, and religion, we need a coherent system of concepts and laws within which the natural sciences, as well as philosophy and the humanities, have their place. Such a system may be called 'philosophy of science.' (Frank 1957: xiv-xv.)

To acquire a quite comprehensive point of view of the problems and tasks of this endeavor Frank studied (and eventually published almost exclusively on this subject in the 1950s) those (to use his different terms) 'existential', 'ideological', 'pragmatic', 'sociological', 'political', and 'extra-scientific' factors which played a crucial role in the acceptance, denial, and dissemination of scientific theories. He was very well aware of the significance of the Cold War situation (not just at Harvard) which called for the examination of science and various values in a liberal democracy. Thus, in Carnap's eye, Frank was the same 'earthly' figure as Neurath:

[Frank] made important contributions to the discussions in the Circle or in private talks and also by his publications. He was familiar with the history of science and much interested in the sociology of scientific activity, for which he collected comprehensive materials from history. Both because of his historical interest and his sound common sense, he was often wary of any proposed thesis that seemed to him overly radical, or of any point of view that seemed too formalistic. Thus, in a way similar to Neurath, he often brought the abstract discussion among the logicians back to the consideration of concrete situations. (Carnap 1963: 32. Emphases added.)

The last strand of Frank's general interest was his educational work. He taught courses at Harvard on various topics in physics, philosophy, and science. Education was meant to be one of the most important fields of activity for Frank since he sensed some major problems among young students at the university. He wrote to Neurath:

From the viewpoint of empiricism, one thing is striking. Students who have had very little scientific training are, unconsciously, influenced by a sort of vulgarized scholastic philosophy. They may have put up from the church or from 'philosophical introductions' to textbooks or what not. Before the

\footnotetext{
7 About the Machian and Austrian line of Frank's philosophy see (Mormann 2017).
} 
science teaching got a certain grip on these boys, they were genuine Aristotelians. (Frank to Neurath, December 10, 1943, Otto Neurath Nachlass.)

His most remarkable achievement was a course on "Contemporary Physics and its Philosophy, a Philosophical Interpretation”. Frank started the course in the early 1940s with 15 students and later it evolved into a significant event sometimes with 250 participants. ${ }^{8}$ During these courses Frank emphasized the importance of science and philosophy of science with "educational purpose" (Frank 1956/1958: 19) and due to his exceptional teaching skills ("[h] could explain so simply because he understood so clearly", a comment about Frank quoted by Holton (2006: 302)) his significance as a teacher and promoter of the basic ideas of logical empiricism had an important, though later underestimated influence on philosophy of science in the United States. That strand and line of history still require reconstruction and evaluation.

The five interpretative-historical papers in this special issue draw attention to some forgotten subjects and breathe new life into old subjects. Though approaching Frank's intellectual milieu and his polished thinking may result in important philosophical and historical results, his case documents quite well some general ideals and the fate of logical empiricism in general.

In the late 1940s, Gerald Holton was Frank's teaching assistant and helped in organizing various discussion groups led by him. In his essay, "Philipp Frank and the Wiener Kreis: from Vienna to Exile in the USA", which contains many personal recollections, Holton traces Frank's (and thus the Boston University Colloquium for Philosophy of Science) line of ideas to their original Eastern-European context. By taking into account the "bankruptcy of science" problem, Holton shows how Frank's philosophical and scientific thinking emerged in Europe, and how it was put together again in the U.S.

One of Frank's most important tasks was to defend the theory of relativity, first encountered in Vienna and later in Prague, against the many forms of cultural, scientific, and political attacks. Thus his general oeuvre and legacy is related to various struggles against the then current American socio-political scene. As far as morality as a part of social and political life is concerned, Anne Siegetsleitner claims that Frank's primary interest was to show that as in science, moral relativity does not preclude objectivity. Siegetsleitner's paper deals with the question of which conceptions of relativity and relativism Frank refers to in the context of modern science and examines the implications for objectivity and absolute values in morality.

In his paper, George Reisch examines the relationship between Frank and James Bryant Conant, the then president of Harvard. He focuses on two issues that engaged leading American intellectuals in the mid-twentieth century: the place of metaphysics in higher education and the responsibilities of intellectuals as educators to defend democracy against the rise of totalitarianism. By discussing how Frank arrived and found a job in the United States, and his participation at the New York conferences on Science, Philosophy, and Religion, Reisch suggests that Frank's

\footnotetext{
8 About Frank's educational ideals see (Matthews 2004).
} 
relationship to pragmatism was nourished by his professional and intellectual relation with Conant, and that their individual contributions to our understanding of science are inseparable from their efforts to engage their fellow intellectuals as well as the public in these pressing issues of their day.

After Reisch's description of the intellectual background of Frank's pragmatic turn, a similar move is discussed by Amy Wuest. She concentrates on Frank's account of simplicity, which is not restricted to the epistemology of scientific theories. Frank's treatment of simplicity provides us with a way of accounting for the influence of social and political agendas on the rejection of scientific theories. Wuest traces the development of Frank's account of simplicity from 1947 to 1954 and explains how these considerations came to inform his mature ideas in 1954. Furthermore, she demonstrates the continued relevance of Frank's thought by showing that it can be helpfully applied to a contemporary issue associated with the rejection of scientific theories.

Finally, after the various accounts of how life in the United States transformed Frank's conceptions, Adam Tamas Tuboly considers the narratives according to which Philipp Frank's decline in the United States started in the 1940s and 1950s. Though these accounts capture a kernel of the truth, they are not the whole story: Frank aimed to restore the unity of logical empiricism after all. His approach was centered on sociology and the sociological aspects of science and knowledge and, as Tuboly argues, the same tendency, i.e. the reunion of the sciences and the humanities, could be detected in his sociology and philosophy of science as well as in his reading of Carnap's metaphysics-critique. But Frank's intention was never recognized entirely, partly due to the tendencies of American philosophy and sociology in the second half of the twentieth century, so his conception of unified science and logical empiricism died with him.

Acknowledgements I am indebted to the Carnap Archive at Pittsburgh (Rudolf Carnap Papers, 1905-1970, ASP.1974.01, Special Collections Department, University of Pittsburgh) for the permission to quote the archive materials. All rights reserved. This special issue was supported by the ÚNKP-16-4-II New National Excellence Program of the Ministry of Human Capacities and the "Lendület grant" (No. 2017-287), "Morals and values in modern science."

\section{Bibliography}

Carnap, R. (1963). Intellectual autobiography. In P. A. Schilpp (Ed.), The philosophy of Rudolf Carnap (pp. 3-84). La Salle, IL: Open Court.

Einstein, A. (1912/1993). Report to the Philosophical Faculty of the German University on a successor to the Chair of Theoretical Physics. In M. J. Klein, A. J. Kox, \& R. Schulmann (Eds.), The collected papers of Albert Einstein. Volume 5. The Swiss years: Correspondence, 1902-1914 (pp. 470-473). Princeton: Princeton University Press.

Feyerabend, P. (1988). Against method (5th ed.). London, New York: Verso.

Frank, P. (1938/1949). Ernst Mach and the unity of science. In Modern science and its philosophy (pp. 79-98). Cambridge: Harvard University Press.

Frank, P. (1947). Einstein: His life and times. New York: Knopf.

Frank, P. (1949). Introduction: Historical background. In Modern science and its philosophy (pp. 1-52). Cambridge: Harvard University Press.

Frank, P. (1956/1958). Introductory address. Synthese, 10, 15-19. 
Frank, P. (1957). Philosophy of science: The link between science and philosophy. Englewood Cliffs, NJ: Prentince-Hall.

Frank, P., \& Rothe, H. (1911). Über die Transformation der Raum-Zeitkoordinaten von ruhenden auf bewegte Systeme. Annalen der Physik, 34, 825-855.

Frank, P., \& von Mises, R. (Eds.) (1925-1927). Die Differential- und Integralgleichungen der Mechanik und Physik, I-II. Braunschweig: Vieweg.

Hardcastle, G. L. (2003). Debabelizing science: The Harvard Science of Science Discussion Group, 1940-41. In G. Hardcastle \& A. W. Richardson (Eds.), Logical empiricism in North America (pp. 170-196). Minneapolis, London: University of Minnesota Press.

Hofer, V. (2002). Philosophy of biology around the Vienna circle: Ludwig von Bertalanffy, Joseph Henry Woodger and Philipp Frank. In M. Heidelberger \& F. Stadler (Eds.), History of philosophy of science. New trends and perspectives (pp. 325-333). Dordrecht: Springer.

Holton, G. (2006). Philipp Frank at Harvard University: His work and his influence. Synthese, 153(2), $297-311$.

Isaac, J. (2012). Working knowledge. Making the human sciences from Parsons to Kuhn. London, Cambridge, MA: Harvard University Press.

Matthews, M. R. (2004). Reappraising positivism and education: The arguments of Philipp Frank and Herbert Feigl. Science \& Education, 13, 7-39.

Mormann, T. (2017). Philipp Frank's Austro-American Logical Empiricism. HOPOS, 7(1), 56-87.

Reisch, G. (2005). How Cold War transformed philosophy of science. To the icy slopes of logic. Cambridge: Cambridge University Press.

Schulmann, R., Kox, A. J., Janssen, M., \& Illy, J. (Eds.). (1998). The collected papers of Albert Einstein, Volume 8. The Berlin years: Correspondence, 1914-1918. Princeton: Princeton University Press.

Siegmund-Schultze, R. (2007). Philipp Frank, Richard von Mises, and the Frank-Mises. Physics in Perspective, 9(1), 26-57.

Stadler, F. (2001/2015). The Vienna Circle. Studies in the origins, development, and influence of logical empiricism (2nd ed.). Dordrecht: Springer.

Stöltzner, M. (1995). Philipp Frank and the German Physical Society. In W. Depauli-Schimanovich, E. Köhler, \& F. Stadler (Eds.), The foundational debate. Complexity and constructivity in mathematics and physics (pp. 193-203). Berlin: Springer. 